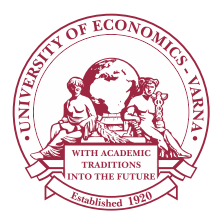

Izvestiya Journal of Varna University of Economics 3 (2021)

IZVES T I YA

Journal of Varna University of Economics

http://journal.ue-varna.bg

\title{
REGULATION, COMPETITION AND PARTNERSHIP IN THE FINANCIAL SECTOR
}

\author{
Stefan VACHKOV ${ }^{1}$, Nedyalko VALKANOV ${ }^{2}$ \\ ${ }^{1}$ Department of Finance, University of Economics, Varna, Bulgaria, \\ E-mail: vachkov@ue-varna.bg \\ ${ }^{2}$ Department of Finance, University of Economics, Varna, Bulgaria, \\ E-mail: n.valkanov@ue-varna.b
}

JEL: G18, G28, O30

Key words:

Financial regulation, Banks, BigTechs, FinTech, RegTech

\section{Abstract}

This article analyses current regulatory tendencies, provoked by the entry of the BigTechs in the financial services segment. Against that background, new forms of cooperation between financial institutions and the possibilities for their partnership with the financial regulators are reviewed.

(C) 2021 University of Economics - Varna

Citation: VACHKOV, Stefan, VALKANOV, Nedyalko (2021). Regulation, Competition and Partnership in the Financial Sector. Izvestiya Journal of Varna University of Economics, 65 (3), pp. $259-276$.

DOI: 10.36997/IJUEV2021.65.3.259

\section{Introduction}

The entry of new technologies in the financial sector impacts the approaches for its regulation. The presence of the FinTech industry and the BigTechs increases the competition with the traditional players on the financial services market, but at the same time traces the road to new forms of partnership. The previously conservative bank industry changes fast and starts offering innovative products, services and hybrid solutions, produced and distributed within multiplatform ecosystems. All this is supported by the blockchain, cloud technologies and AI, quickly entering our everyday life.

Against that background, more often than not, the regulatory bodies resort to smart-technology-based expert opinion. The subject of the study in this article 
are the challenges before the regulation of the FinTechs and the BigTechs. Special consideration is given to the strategic partnerships between financial intermediaries and the regulators.

\section{Regulatory focus on the new competitors}

It is known that the economic and business role of the banks may be fully realized only with a stable regulation. When it receives a license, the credit institution has signed the rules for consumer protection, which protect my money, if it goes into bankruptcy. In other words, a bank is a guaranteed value vault, licensed by the government and the insured person. This is the reason why the newly founded companies cannot be called banks, since the use of the word "bank" in a trademark is legal only if the company holds a state license. Yes, this creates a symbiotic relationship with the regulators, but they also recognize the actions of the banks. That is why they sanction them. Does this mean that they protect them from the competition? Not exactly. But it protects them from the competitors, who are trying to do exactly the same, but without balance sheets and audits (Skinner, 2018).

Let us first mark "the regulatory considerations" regarding the FinTechs, also called "the young and crazy in the financial industry" (Burgmaier, Hüthig, 2015, S. 102). These HighTechs use the advantages of IT and unlike the banks, they offer financial products and services in a completely new form, clearly customer-oriented, with much more tangible benefit for the customers. Although they very often do not have the required regulatory permits (instructions), these companies report significant growth at the expense of a forced placement and/or due to their entry on larger market sections in the regulated zone. But will regulation help them replace the traditional operators?

First. The results of the bank sector are measured in real return (of income for shareholders, equity, investments etc.) and the market presence of the FinTechs - in hope, because behind it is only "a world of promises".

Second. The regulators and the shareholders regard the banks as depositories (...), which deal with capital and risk and use technology to manage these issues. This has nothing to do with innovations, vision, interruption, change. It is all about stability, sustainability, reliability and security. If this leads to change and risk, then the investors and regulators will go bankrupt (Skinner, 2019). Then it is logical for the customers to welcome any regulation, which guarantees them more security.

Third. The regulations and instructions for compliance are a domain, where not only do the banks have the most benefit and can employ competitive advantages, but also use them as a weapon against Tech startups to maintain control over the customers 
Stefan Vachkov, Nedyalko Valkanov.

Regulation, Competition and Partnership in the Financial Sector

and keep the market share (Zaheer, 2015). For this purpose, however, the credit institutions must be fast, decisive and taking a stand with the clear support of the top management, to form the market and not wait for newer and more strict regulations for the FinTechs (Beier u.a., 2016, S. 10).

Fourth. While the banks are subject to a single and complex regulation, the FinTechs are subject to regulation by various supervision bodies according to the respective business. This creates significant discrepancies between the regulatory parameters and the costs for compliance, which impact negatively the competitiveness of the vaults due to the more detailed requirements for them and their high regulatory costs.

Fifth. In recent years more and more large FinTechs receive a banking license, place themselves on "the right side of the regulation" and achieve a number of benefits (Goel, 2019): cheaper access to capital; quick customer penetration; growing revenues at the expense of increasing the variety of products/services sold (including other FinTechs); increased trust by customers and investors; bigger attractiveness of the company brand etc.

Sixth. The "compression" of the regulation would impact negatively the cost base for many FinTechs, which would stimulate consolidation processes in that sector. The concentration of the business in less, but stronger market participants will increase the competition concerns of the traditional banks. At the same time, following the regulatory requirements may create obstacles before the FinTechs for sales, for example due to the obligation for customer identification when applying the measures against money laundering.

Seventh. The long-term chances of success may attest to an innovative product only when the FinTechs business model is not forced to remain unregulated. This almost always excludes the possibilities for development of product offers and further growth.

But when will the regulators start to take these innovative competitors more seriously? At least until now the governments of the USA and some Member States of the European Union are cautious, trying to put the FinTechs in the existing regulatory structures and offering a one-time settlement of companies, which would like to follow the rule. Initially, other countries embrace a more open approach and restrict themselves only after seeing that there were problems with consumer protection, cyber risks or frauds, as it happened in China in 2016 and again in 2019, when many partner lenders appear in the country and are recognized as predatory (Mayor, 2021).

Since the constant product innovations make the intervention of the regulation on each new activity/product meaningless, it is justified only if the innovations "promise" losses for the consumers and/or breaches in management. The FinTechs, whose offers cover the market expectations quickly and effectively, are hardly worried by 
such situations. It must also be considered that the innovation provokes regulatory interventions only when it "develops" enough cases and consumers.

Similar observations can be made regarding the market aggression of the BigTechs - "the new dynamic power in the financial ecosystem" and the more serious threat to the traditional banks (Srivastav, 2019). They do not follow the strict requirements (for equity, risk models, customer protection, privacy, fight against money laundering etc.), they are not subject to supervision by state institutions, they provide key technologies to the banks (cloud services, AI etc.) and they offer products similar to banking. All this presents the regulatory institution with a number of questions.

First. The widening presence of the BigTechs stimulates financial innovations, but can lead to forming oligopolistic markets with all arising circumstances: restriction of the competition, decrease of the efficiency of the financial industry and appearance of new system risks (Frost et al., 2019, p. 21). In other words, in the future, a small number of BigTechs may dominate and not diversify the provision of specific financial services in some jurisdictions. If this happens, the failure of these companies may lead to widespread interruption. In particular, this may present a risk, if the BigTechs' activities in the financial services are not accompanied by a suitable risk management and regulatory supervision or if the customers of the BigTechs are not able to easily pass to other providers of financial services (Skinner, 2020a).

Second. The fact that the BigTechs do not have enough experience in risk management will force them to demonstrate herd behavior when facing market shocks and increasing the procyclicality. Also, there is a larger possibility for the BigTechs to engage in universal banking. Some of them are already becoming financial holdings, which increases the possibility to infect risk markets and sectors (Jun, 2018, p. 5). It is possible for part of the traditional bank services to remain outside the technological titans' business, but others - with lower barriers for entry (e.g. transactions) - may be exposed to the risk of long-term "interruption". If all other conditions are equal, their negative attitude towards risk management in all its forms (due to the stricter regulatory intervention, the exponentially growing costs and the decreasing attractiveness of the transactions) is in favor of the banks.

Third. It is not clear how the regulators will evaluate the potential impact of the BigTechs' expansion on the financial industry and its customers. For example, whether and to what extent to account for the uniqueness of their business models, which are the result of the winning combination "big data analysis - access to external networks - interlinked activities". Underestimating it increases the suspicions of a "regulatory gap", creating unequal conditions on the financial markets, disruptions in banking and negative consequences for the customers.

Fourth. This status quo is maintained also due to the regulatory steps taken on 
Stefan Vachkov, Nedyalko Valkanov.

Regulation, Competition and Partnership in the Financial Sector

the various markets in order to increase the transparency and competition, but keeping the lower barriers to entry. Among the most radical are the initiatives for providing open access to financial data to customers (with the consent) of service providers, who are not banks. They were a significant catalyst for new competition by the technically oriented participants (Barua et al., 2019, p. 11). This is a reason for the banks to fear the BigTechs, because these companies can quickly reach significant scale in the financial services through their digital platforms, using their rich knowledge on potential customers (Godsall et al., 2019, p. 6).

Fifth. The regulatory institutions also fear the large volume of data, to which the BigTechs can have access, respectively the way, in which they intend to use it. It is enough to recall how in 2018 Facebook was drawn into the line of fire due to processing of sensitive user data and the attack against its computer network disclosed information on almost 50 million users. Or the case with the disclosed personal information of 500 000 users of the Google+ social network, which Google tries to hide from the public. If the large technological platforms provide better access to their huge arrays of customer data, will the banks be able to acquire more data, which to use when evaluating the loan applications? (Wack, 2021).

Sixth. The regulation restricts the scope of the BigTechs regarding customer deposits and directs them to "niche" products/services - payments, credits for natural persons or SMEs for provision of working capital etc.

The bold innovative solutions of leading BigTechs (Apple, Amazon, Square, Uber, Google, Facebook etc.) are a serious reason for the legislators to restrict their strive for wide scale placement in the financial services sector. The stricter regulations may be estimated not only as a threat, but as a chance to neutralize the BigTech competitors and "the sophisticated FinTechs". They must not be allowed to provide services, which are competitive to the banks, without following the same rules. In this sense "the feeling that the stricter regulation - if applied universally - can ensure the advantage of the established financial institution before the new competitors, goes outside the technology frame" (Armstrong et al., 2021).

Therefore, the regulators must seek opportunities to provide equality between them and the banks with the clear understanding that the "fitting" of the BigTechs in the contemporary social and economic landscape requires new and complex compromises between the financial stability, the competition and the data protection. They could be achieved through active coordination between the competent bodies on the national and cross-border level.

It is also understandable that in the foreseeable perspective the regulatory bodies will be divided between their desire to encourage competition and innovations and to ensure reasonable supervision of the occurring violations. In search of a way out of 
this dilemma, they must find suitable "critical" differentiators, which personalize these "objects". These may be: results from alternative data analyses helping to generate unique information; conclusions from comparisons of product specifications; results from identification of "painful points" in the customer "trip"; customer experiences from purchasing new products; studies of the state of customer migration etc.

\section{Regulation and strategic partnerships}

The headlong "march" of the innovative digital players on primeval bank "territories" forces the classic vaults to copy their market behavior. If they do not do so, they risk to fall in a set of risky, capital intensive and low revenue businesses, while the digital giants or the more aggressive traditional competitors side up with the businesses most attractive to them - deposits of natural persons and small enterprises, payments and wealth management. These are areas, in which the brands of the digital giants, the customer databases and the technological complexity give them significant advantages (Kumar et al., 2019).

Apparently, the vaults have no other alternative than to respect this time imperative. By introducing a fully open banking model and cloud-based application programming interfaces, they will be able to implement the most successful ideas for "open banking" of the newly emerging world of FinTech (Skinner, 2020b). This way, the bank industry must show that it can be trusted not only with the help of general customer information, but because it can add value by using this data to improve the financial status of its customers without requiring them to do all the work themselves (McIntyre, 2020, p. 8).

Although the regulatory barrier still impedes the breakthrough of innovative financial services suppliers, more and more bank managers see a saving alternative in partnering with them under different forms. For example, as part of the big banks' ecosystem, the FinTechs will benefit from their regulatory expertise on existing infrastructure, processes, reporting, accountability, risk management, requirements for trade in securities, data protection, measures against money laundering etc. This way, the credit institutions will assist them in optimizing their business models, but at the same time will be able to "dictate" the parameters of the partnering "regulatory code".

It is assumed that the integration of the FinTechs in the existing regulatory practices of banks will be easier and faster than the creation of a new regulatory framework for the FinTechs. The power of this effect depends on various factors, more specifically on the choice of a regulatory scope for the cooperation model and its underlying products and services (Beier u.a., 2016, S. 9). But before entering into partner relation, both parties must be aware of the rules for regulatory compliance. For the bank this means to learn more of the actions of the FinTech for guaranteeing that the existing regulations 
Stefan Vachkov, Nedyalko Valkanov.

Regulation, Competition and Partnership in the Financial Sector

would be followed and for decreasing the risk of frauds (Raspa, 2020).

It is clear that the current model many regulations for various market segments has no chance of survival in a financial mediation world "possessed" by digitalization. Then it is completely logical for the credit institutions not to be strictly regulated themselves. On the contrary, if the same transactions follow the same rules, the chances and risks between the market players may and should be distributed symmetrically. Partners operating under the same banking standards as you, with unified processes and regulated protocol, stay in the business for a long time. They value their status of legal providers and help the small enterprises grow with priority. By helping managing the burden of compliance, the FinTechs can give to the smaller banks the chance to compete with the larger institutions through reducing the overheads (Singer, 2016).

How will the regulation bring the banks, the FinTechs and the technological players together, and who will sit on top? We know that this will depend on the data use, the engagement of user experience and exceptional risk management, but it is still unclear how the existing condition and regulatory structure of the different countries will define the development of it all (Finextra Research 2020b). Positive indications for solving these issues are not lacking. They come from the now forming mega platform environment (ecosystem), which integrates technological giants, FinTechs and traditional bank institutions. This new reality must be projected over a "mirror" regulatory platform. From regulatory point of view, such is the Payment Services Directive (PSD2). It institutionalizes the revolution in the transfers' domain, gives green light for the development of "open banking" and outlines some basic regulations (e.g. the requirement for 3 factor identification). On the institution level the large regulatory change is embodied by two innovations - the RegTech segment and the SupTech initiative of the supervision bodies.

The following stand out among the key competitive advantages of the RegTechs: the possibility for complex analysis of large data arrays; the quickness in configuration, generation and processing of information for regulatory reporting; the flexibility of integration between various processes and platforms; the possibility for smart processing of databases via AI (Deloitte, 2016, p. 5).

In general, there is no single interpretation of the RegTechs. The reasons for this are their flexible variations and the relatively small and flexible structures, through which they operate. The analysis of their product range might bring more clarity as to their profile. It includes products ensuring the execution of basic operation in the fields of: compliance; operation supervision; customer ID verification; non-compliance risk management; regulatory disclosing and reporting; automated tracking of regulatory changes.

According to research for the Cambridge Center for Alternative Financing 
(CCAF), the biggest share among the regulatory areas, "covered" by the RegTechs (over $50 \%$ ) is for the customer identification activities (the "Know Your Customer" policy $\mathrm{KYC}$ ), followed by the provision of measures against money laundering, financing of terrorism and compliance with the imposed penalties (Schiaz et. al., 2019, p. 37). This is completely logical given the record sanctions borne by the financial sector in recent years for allowed non-compliance exactly regarding these modes of regulation.

The growing regulatory complexity also determines the need of a completely new reporting availability. It will allow generating information from dozens (and in some cases hundreds) of various information arrays - customer files, analytical reports, operational logs, logs for transactions with payment tools, data backups and many more. Since the traditional information and accounting systems of the financial intermediaries cannot always provide this whole informational variety directly, the RegTechs turn out to be the necessary external supplier of regulatory expertise facilitating the achievement of regulatory compliance of the ever more complex external environment.

A research of the Basel Committee on Banking Supervision defines the following direct benefits for the bank sector from cooperating with the RegTechs: 1) stimulating the appearance of new processes, distribution channels, products or new business organizations, cooperating for compliance with the regulatory requirements and more effective risk management, including through outsourcing or insourcing processes; 2) digital transformation of the control and maintenance functions in the banks (risk, compliance, legal regulations, finances, IT); 3) widening the scope of requirements for regulatory reporting, financial crimes, operational risk (including cyber security and uncovering frauds), consumer and data protection (BCBS, 2017, p. 23-24).

The trends described above illustrate the impossibility for unilateral financial supervision based on the traditional vertical approach. Even back in the years after the global financial crisis of 2007-2008 the supervision bodies rethink their policies looking for new forms of partnership. It was initially applied under the influence of macroprudential regulatory policies. They integrate the activity of separate financial regulators under the direction of a single prudential body, located on its own or integrated in the architecture of one of the traditional supervision agencies - a central bank for example.

The second stage of the "opening" of the regulators is the search for cooperation within their innovative initiatives. It provokes the appearance of supervision technologies (SupTechs), uniting the application of high-tech solutions for the needs of financial supervision, separately or through partnering with other providers of regulatory and technological expertise (such as the RegTechs).

The development of supervision technologies passes through four stages. First, descriptive analysis based on manual data processing and validation. Second, 
Stefan Vachkov, Nedyalko Valkanov.

Regulation, Competition and Partnership in the Financial Sector

digitalization and automation of specific hard copy and manual processes, allowing deeper diagnostic analysis. Third, transition to large data processing architecture, allowing to manipulate information with more detail, variety and frequency. Fourth, use of AI (ECB, 2020).

The agenda also includes the so-called Regulatory Sandboxes, whose development creates a sort of test environment for testing and subsequent integration of various high-tech solutions. For example, for data collection (modules for automated reporting, real-time supervision, reporting information consolidation, data visualization etc.) or for information analysis with the help of tools for risk assessment, market supervision, fraud prevention, money laundering, terrorism financing etc.

Outside their purely technological contribution, the Regulatory Sandboxes are a potential new area for partnership between supervision bodies, central banks, traditional financial institutions, FinTechs and RegTechs. According to a study of the Financial Stability Council, the largest share among the SupTech initiatives goes to the partnership between separate supervision bodies (regulators and central banks), followed by that between other sector regulators, government agencies, third parties - providers of technological expertise, SupTech companies, academic institutions etc. (FSB, 2020, p. 14). It also becomes clear that the supervision and regulation technologies have the potential to increase the sustainability of the financial system, to decrease the human errors and to increase the possibilities for real time supervision. Together with this, one must also consider the potential risks of creating an excessive dependency on the SupTechs and RegTechs (FSB, 2020, p. 3).

Under certain conditions, we could identify several levels of interaction within the individual SupTech ecosystems: 1) own development activity trough own development and testing of various innovations by the supervision agencies; 2) attracting companies from the RegTech domain as providers of technological expertise; 3) cooperation with traditional financial institutions; 4) partnership with FinTechs. Most often these are manifested within joint test environments (sandboxes, accelerators, innovation hubs), where the participants are regulators, RegTechs, traditional and innovative providers of financial services.

It must be noted that the prerogatives of the supervisory bodies are not and should not be subject to revision. This is rather about a new concept for an integration approach. In other words, the classic relationship between regulators and regulated subjects is kept in parallel with the attraction of new "partners", gravitating around the FinTech and RegTech sector. Even more, their participation as providers of both technological and regulatory expertise at the same time increases the efficiency of the supervisory process. 


\section{Funding and acknowledgements}

This research has received funding from the European Union's Horizon 2020 research and innovation program FIN-TECH: A Financial supervision and Technology compliance training programme under the grant agreement No 825215 (Topic: ICT-352018, Type of action: CSA).

\section{Endnotes}

${ }^{1}$ Skinner, 2019.

${ }^{2}$ First, it is completely clear that the FinTech startup is evaluated based on potential, not on reality. When Stripe costs more than three Commerz Banks or it is evident that Ant Financial costs more than ten Deusche Banks, then it is certain that the bank executives are a little angry (Skinner, 2019).

3 Which innovation can attract the attention of the regulators? Are these the alternative means for cross-border transfer of funds? Is it probable for those using crypto currencies to do so? Despite the popular belief that the disintermediation of banks in the process is what worries regulators, maybe this is not so; maybe it is rather the disintermination of regulation that the regulators are concerned with (Prabhu, 2017).

${ }^{4}$ In most countries, the bank industry is also structured on an oligopolistic principle, i.e. it is dominated by a small number of large credit institutions. In this reality and due to the relatively low priority, which banks assign to innovations, the customers are faced with serious problems regarding the quality, diversity and accessibility of service.

${ }^{5}$ Some risks are similar to those for the financial companies in a wider sense (including the FinTechs) and were subject to a previous work by the Financial Stability Fund (FSB). They include financial risks occurring from the leverage, maturity transformation and liquidity mismatches, as well as operational risks, including those that could occur from potential faults in management, risk control and processes (Skinner, 2020a).

${ }^{6}$ These elements are viewed as the DNA of the BigTechs' business models. The "network external effects" of the BigTechs' platform are related to the fact that the user's benefit from participating as a party on the platform (e.g. as a seller in an e-trade platform) increases with the number of users acting as the other party (e.g. as buyers). The external networks create more users and more value for them. They allow the BigTechs to generate more data - the key contribution to data analysis. The analysis of large data arrays improves the existing services and attracts additional users. On their part, most users provide to the critical mass of customers the possibility to offer 
Stefan Vachkov, Nedyalko Valkanov.

Regulation, Competition and Partnership in the Financial Sector

a broader range of activities, which bring even more data. Therefore, the external networks are stronger on platforms offering a broader range of services and represent an essential element in the BigTechs' life cycle" (BIS, 2019, p. 62).

${ }^{7}$ After all, the growing market power of the BigTechs provoked the first regulatory interventions. In Europe and the United States these interventions were focused on data violations by the BigTechs, which have not affected banking so far. In China the relatively fast growth of the BigTechs' banking business already has discrete regulatory effects. The Chinese government forces the BigTechs to keep $100 \%$ of their customers' deposits as a minimum reserve in the Chinese Central Bank. In June 2018 , the government also introduced new rules for using central, state clearing houses (Sachverständigenrat, 2019, S. 226).

${ }^{8}$ In the same sense others note that the banks and credit unions fear the BigTechs mostly due to their large access to data and their capacity to manage the customer experience. But "despite that, between the anti-monopoly regulations, the investigation of algorithms and states, focused on the privacy rules (...), it is hard to imagine to what extent the technologies will be able to use the nuts and bolts of the bank industry" (Williams, 2020).

${ }^{9}$ If in the past the credit cards were a high margin product for the banks, today these institutions are facing a new competition in the era after the crisis (Wack, 2020). According to others, in the emerging markets and the developing economies the BigTechs provide broader range of financial services, such as credits, insurance and asset management. This change may be due to the differences in the financial development, the approaches to financial regulation and the entry of financial services in different geographic areas (Skinner, 2020a).

${ }^{10}$ In particular, the plainly called "Keep Big Tech Out of Finance" Draft Act in the United States, which is "very unlikely to pass, at least in the present political environment, but this situation may quickly change depending on the circumstances" (American Banker, 2020).

${ }^{11}$ It is assumed that the development of the BigTechs will impact the formulation and application of the monetary policy. The rise of the BigTechs will increase the competition in the financial industry, making the market more sensitive to changes in interests, which could improve the efficiency of the price-based tools of the monetary policy. But, with the advancement of technology, the share of intangible assets in the total assets of the companies will continue to grow, which could undermine the efficiency of the monetary policy. In addition, the BigTechs can impact the inflation when the frequency of price change increases by quickly regulating the prices of goods and technologies through algorithm technologies (Jun, 2018, p. 5).

${ }^{12}$ They are extracted from non-traditional sources, such as the "Internet of 
Things", integrating billions of linked sensors and devices (26.66 billion in 2019 and expected 75.44 billion in 2025) in countless contexts (Crosman, 2020). Since they are anonymous i.e. they do not contain personal data, the same can be used without fear of violating regulatory requirements. Depending on the specific type, the alternative data may be collected and analyzed weekly, daily or even every minute. This makes it much more dynamic and rich than the traditional data source. With their help and in combination with other information sources, very intelligent analyses can be made in a large scope - from customer behavior to market trends.

${ }^{13}$ The new Apple credit card (defined as one of the most successful innovations in the card sector in recent years) is part of the recent invasion of Goldman, aiming to direct the attention to the consumers on Main Street after more than a hundred years, in which it took care of large corporations and big investors. Its partner in the endeavor - Apple Inc. - tried to decrease to a minimum the role of the investment bank, since it offers the product on the market with a sign that says: "A new kind of credit card. Created by Apple, not by a bank." (Natarajan and Nasiripour, 2019).

${ }^{14}$ The European Bank Authority (EBA) defines a set of key challenges before the trust, which the financial institutions and regulatory bodies face due to the increasing use of large data and extended analyses (including machine learning) in the financial services sector. The set defines four main pillars for aiding the integration of extended analyses (data management, technological infrastructure, organization and management and methodology for analysis), as well a set of "trust elements", which must be correctly and sufficiently reported. Considering that two of three credit institutions in the EU have already made such "production" decisions, this measure is completely in good time (Finextra Research, 2020a).

${ }^{15}$ In particular, the application of the "Level Playing Field" principle, according to which all market participants making the same transactions must follow the same regulatory rules. According to some, however, in so far as these startups receive more air time, the regulators will guarantee that the FinTechs play by the same rules, but maybe not under the same conditions (Jaros, 2021).

${ }^{16}$ The other current legislative initiative in this direction is the single European regulatory framework for crypto assets processing (the Markets in Crypto-assets Regulation - MiCA). See the details in: Regulation of the European Parliament and of the Council on Markets in Crypto-assets, and amending Directive (EU) 2019/1937, 24.9.2020, https://eur-lex.europa.eu/legal-content/EN/TXT/HTML/?uri=CELEX:520 20PC0593\& from=EN.

${ }^{17}$ According to some authors (Barberis et al.) the appearance of RegTechs dates back to the 90s of the 20th century and the first years of the new Millennium and is associated mostly with the development of own technologies for value at risk reporting 
Stefan Vachkov, Nedyalko Valkanov.

Regulation, Competition and Partnership in the Financial Sector

according to the then acting capital regulations and for following the regulatory requirement to monitor unusual shifts in the markets for securities. Also, while the rise of the FinTechs is nurtured by the many appearing startups, falling in direct competition with the traditional financial institutions, the entry of the RegTechs is a response to the institutional demand for regulatory "top-to-bottom" expertise as a result of the increasing costs for regulatory compliance. See the details in: Barberis et al., 2019, pp. vi-ix.

${ }^{18}$ For the variety of RegTechs, see the details in: Deloitte, 2018; Schizas et al., 2019.

${ }^{19}$ The periodic reports of the CCAF data summarize information from over 2,300 platforms for alternative financing from all over the world and are often used in publications on the subject by global institutions such as the Basel Committee on Banking Supervision, the Financial Stability Council etc. All CCAF reports are accessible online at: https://www.jbs.cam.ac.uk/faculty-research/centres/alternativefinance/publications.

${ }^{20}$ The cited research also summarizes the services most often offered by the RegTech sector. Over half of the regulatory expertise companies offer solutions related to collecting and reporting information, data analysis, risk identification and management. The regulatory information management, the fund transfers supervision and analysis, the investigation of frauds and misconduct are also popular RegTech services.

${ }^{21}$ The significance of the RegTech is also proven by the size of investments in that segment, which according to some analysts (Juniper Research) in 2024 will be five times their volume in 2019 resp. \$ 127 billion. According to the research, the main cause of this growth is the dramatic increase of separate processes, requiring high degree of automation and mostly those in the domain of customer identification (Juniper Research, 2019). These forecasts are also confirmed by the data from 2018, for which year some analysts report 2,5 times increase compared to the previous and almost 5 times growth of investments in the sector within five years, where the largest growth in the 2014-2018 period is for the investments related to covering the new regulatory requirements in the customer identification domain - KYC $(+34.5 \%)$, counteracting the money laundering - AML (+28\%), GDPR (+13.1\%), MiFID II (+6.4\%), Basel III $(+2 \%)$, PSD $2(+2 \%)$ etc. (FinTech Global, 2019).

${ }^{22}$ See: Broeders and Prenio, 2018, pp. 5-6.

${ }^{23}$ In this relation, we can point out platforms such as Corda, Ethereum and HyperLedger Fabric, offering basic infrastructure, including an open source one, for forming shared environments with regulators and other government bodies. Another illustration are the separate regulatory initiatives in the high tech domain. For example, 
the developed under the auspices of the European Commission DLT-based decentralized portal for exchange of regulatory information for the publicly traded entities in the EU (Financial Transparency Gateway, EFTG) connects the market infrastructures of the individual EU Member States. We can also mention the projects of the monetary bodies of Singapore, Hong Kong and the Central Bank of Canada to construct a blockchain based infrastructure for exchange of financial information, and the developed in 2018, again under the auspices of the European Commission, International Association for Trusted Blockchain Applications (INATBA). On its part, the ECB regards SupTechs as a key element in its strategies for bank supervision. See the details in: Valverde \& Fernández, 2019, p. 28; Compare with: FSB, 2020, p. 12.

${ }^{24}$ Studying the SupTech initiatives of 39 financial regulators worldwide, some reach the conclusion that the SupTech helps the supervision agencies in becoming more data and technology oriented, but these innovations should also correspond to the size, complexity and development of the regulated sectors. It turns out that the many newly appearing SupTech solutions are still of experimental nature and less than one third of them are active (Di Castri et. al., 2019, p. 2).

\section{References}

1. American Banker (2020). The banking tech trends that will dominate 2020, January 07, Available at: https://www.americanbanker.com/list/the-banking-techtrends-that-will-dominate-2020.

2. Armstrong, R., M. Vandevelde, L. Noonan (2021). Wall Street wants Biden to crimp tech rivals. The Financial Times, February 10, Available at: https://www.ft.com/ content/42f5b047-6b1f-4028-a428-0450d42c5650.

3. Auer, R. (2019). Embedded Supervision: How to Build Regulation into Blockchain Finance, Bank for International Settlements, Available at: https://www.bis. org/publ/work811.pdf.

4. Bank for International Settlements/BIS (2019). Annual Economic Report, June, Available at: https://www.bis.org/publ/arpdf/ar2019e3.pdf.

5. Barberis, J. D. Arner, R. Buckley (2019). The REGTECH Book: The Financial Technology Handbook for Investors, Entrepreneurs and Visionaries in Regulation. Wiley.

6. Broeders, D., J. Prenio (2018). Innovative technology in financial supervision (suptech) - the experience of early users. FSI Insights on policy implementation, No 9, July 2018, Available at: https://www.bis.org/fsi/publ/insights9.pdf.

7. Basel Committee on Banking Supervision, BCBS (2017). Sound Practices: Implications of fintech developments for banks and bank supervisors. Consultative 
Stefan Vachkov, Nedyalko Valkanov.

Regulation, Competition and Partnership in the Financial Sector

Document. Issued for comment by 31 October 2017, Available at: https://www.bis.org/ bcbs/publ/d415.pdf.

8. Barua, Chr., A. Mehta, K. Rajgopal, J. Sengupta, M. Sieberer, M. Dietz, S. Khanna, M. Lemerle (2019). The last pit stop? Time for bold late-cycle moves, McKinsey Global Banking Annual Review 2019. McKinsey, October, Available at: https://www.mckinsey.com/ /media/mckinsey/industries/financial\%20services/ our\%20insights/global\%20banking\%20annual\%20review\%202019\%20the $\% 20$ last $\% 20$ pit $\% 20$ stop $\% 20$ time $\% 20$ for $\% 20$ bold $\% 201$ ate $\% 20$ cycle $\% 20$ moves/mckinseyglobal-banking-annual-review-2019-vf.pdf.

9. Beier, N., H. Neumann, U. Lindheimer, Fr. Stradtmann (2016). Regulierung von FinTechs: Eine Chance für Banken? Empfehlungen für ein Marktumfeld im Wandel. Accenture, Available at: https://www.accenture.com/_acnmedia/accenture/ conversion-assets/dotcom/documents/local/de-de/pdf_4/accenture-fs-asg-fintechregulatorik-final-web.pdf.

10. Burgmaier, St., St. Hüthig (2015). Kampf oder Kooperation - Das Verhältnis von jungen Wilden und etablierten Geldinstituten. // Brock, H. (Hrsg.), I. Bieberstein (Hrsg.). Multi- und Omnichannel-Management in Banken und Sparkassen - Wege in eine erfolgreiche Zukunft, Wiesbaden: Springer Gabler.

11. Crosman, P. (2020). The rise of the invisible bank. American Banker. January 07, Available at: https://www.americanbanker.com/news/the-rise-of-the-invisiblebank.

12. Deloitte (2016). RegTech is the new FinTech. How agile regulatory technology is helping firms better understand and manage their risks. Available at: https://www2. deloitte.com/content/dam/Deloitte/ie/Documents/FinancialServices/IE_2016_FS_ RegTech_is_the_new_FinTech.pdf.

13. Deloitte (2018). RegTech Universe. Take a closer look at who is orbiting the RegTech space, Available at: https:/www2.deloitte.com/lu/en/pages/technology/ articles/regtech-companies-compliance.html.

14. Di Castri, S., St. Hohl, Ar. Kulenkampff, J. Prenio (2019). The suptech generations. Financial Stability Institute. FSI Insights on policy implementation, No19, Bank for International Settlement, Available at: https:/www.bis.org/fsi/publ/ insights 19.pdf.

15. Financial Action Task Force, FATF (2020). Guidance on Digital Identity, FATF, Paris, Available at: www.fatf-gafi.org/publications/documents/digital-identityguidance.html.

16. Financial Stability Board, FSB (2020). The Use of Supervisory and Regulatory Technology by Authorities and Regulated Institutions. Market developments and financial stability implications, 9 October 2020. Available at: https://www.fsb.org/wp- 
content/uploads/P091020.pdf.

17. European Central Bank, ECB (2020). Digitalising banking supervision: an ongoing journey, not a final destination. Speech by Pentti Hakkarainen, Member of the Supervisory Board of the ECB, at the Supervision Innovators Conference, Frankfurt, 30 November 2020, Available at: https://www.bankingsupervision.europa.eu/press/ speeches/date/2020/html/ssm.sp201130_1 c04b855251.en.html

18. Juniper Reaserch (2019). Regtech Spending to Reach $\$ 127$ Billion by 2024, as AI Drives Cost Savings. Press Release, 24 September 2019. Available at: https://www. juniperresearch.com/press/press-releases/regtech-spending-to-reach-\$127-billionby-2024.

19. Expert Group on Regulatory Obstacles to Financial Innovation (ROFIEG) (2019). 30 Recommendations on Regulation, Innovation and Finance. Final Report to the European Commission, December 2019, Available at: https://ec.europa.eu/info/ sites/info/files/business_economy_euro/banking_and_finance/documents/191113report-expert-group-regulatory-obstacles-financial-innovation_en.pdf.

20. Goel, D. (2019). Grown-Up FinTechs Are Turning Into Banks: The Great Rebundling Has Started. MEDICI Research, September 23, Available at: https:// gomedici.com/grown-up-fintechs-turning-into-banks-the-great-rebundling-hasstarted? $\mathrm{s}=8$ fgunq2isrsqtt5tmhri.

21. Finextra Research (2020a). EBA identifies trust challenges from growing use of Big Data and AI in finance, 14 January, Available at: https://www.finextra.com/ newsarticle/35062/eba-identifies-trust-challenges-from-growing-use-of-big-data-andai-in-finance.

22. Finextra Research (2020b). Sibos 2020: Big Tech companies are not looking to get into financial services - Jesse McWaters, 08 October, Available at: https://www. finextra.com/newsarticle/36714/sibos-2020-big-tech-companies-are-not-looking-toget-into-financial-services--jesse-mcwaters.

23. Frost, J., L. Gambacorta, Y. Huang, H. Song Shin, P. Zbinden (2019). BigTech and the changing structure of financial intermediation, BIS Working Papers, No 779, Available at: https://www.bis.org/publ/work779.pdf.

24. Godsall, J., M. Dietz, N. S. Lawson, S. Khann, I. Set (2019). Inflection point: Seven transformative shifts in US retail banking. McKinsey \& Company, October, Available at: https://www.mckinsey.com/ /media/McKinsey/Industries/Financial\%20 Services/Our\%20Insights/Inflection $\% 20$ point $\% 20$ Seven $\% 20$ transformative $\% 20$ shifts\%20in\%20US\%20retail\%20banking/Inflection-point-Seven-transformativeshifts-in-US-retail-banking-vF.

25. Jaros, R. (2021). Improving your bank's digital experience. ATM Marketplace, Feb. 9, Available at: https://www.atmmarketplace.com/blogs/improving- 
Stefan Vachkov, Nedyalko Valkanov.

Regulation, Competition and Partnership in the Financial Sector

your-banks-digital-experience/?utm_source=AMC\&utm_medium=email\&utm campaign $=$ EMNA\&utm_content $=2021-02-09$.

26. Jun, Zhu (2018). The Impact of Fintech and BigTechs on the Financial System. Beijing Global Fintech Summit, Available at: http://www.cf40.org.cn/uploads/ newsletter/20181203.pdf.

27. Kumar, M., S. Saumya, K. Berz, G. Le Boulay, T. Tang, S. Tripathi, I. Walsh, A. Xavier, and Maël Robin (2019). Banks Brace for a New Wave of Digital Disruption. Boston Consulting Group, July 25, Available at: https://www.bcg.com/ publications/2019/banks-brace-new-wave-digital-disruption.aspx.

28. Mayor, T. (2021). Fintech, explained. MIT Sloan School of Management, Feb 4, Available at: https://mitsloan.mit.edu/ideas-made-to-matter/fintech-explained.

29. McIntyre, A. (2020). TOP 10 TRENDS FOR 2020: The weather could get stormy. Accenture, January 7, Available at: https://financialservices.accenture.com/ rs/368-RMC-681/images/Accenture-Top-10-Banking-Trends-2020.pdf.

30. Natarajan, S., Sh. Nasiripour (2019). Goldman Hands Out $\$ 10$ Billion in Credit Lines for Apple Card. // Bloomberg, November 1, Available at: https://www. bloomberg.com/news/articles/2019-11-01/goldman-hands-out-10-billion-in-creditlines-for-apple-card.

31. Prabhu, N. (2017). FinTech - Too Big to Stay Unregulated. Let's Talk Payments, September 18, Available at: https://letstalkpayments.com/fintech-too-bigto-stay-unregulated/.

32. Proposal for a Regulation of the European parliament and of the Council on Markets in Crypto-assets, and Amending Directive (EU) 2019/1937, 24.9.2020, Available at: https://eur-lex.europa.eu/legal-content/EN/TXT/HTML/?uri=CELEX:52 020PC0593\&from $=\mathrm{EN}$.

33. Raspa, R. (2020). How Bank and Fintech Partnerships are Redefining the Future of Banking. Finextra Research, 14 September, Available at: https://www. finextra.com/blogposting/19308/how-bank-and-fintech-partnerships-are-redefiningthe-future-of-banking.

34. Reuters (2019). China gives P2P lenders two years to exit industry: document, November 28, Available at: https://www.reuters.com/article/us-china-p2p/china-givesp2p-lenders-two-years-to-exit-industry-document-idUSKBN1Y2039.

35. Sachverständigenrat zur Begutachtungder gesamtwirtschaftlichen EntwicklungStatistisches Bundesamt (2020). Den Strukturwandel meistern, Jahresgutachten 2019/20, Wiesbaden: Bonifatius GmbH Druck-Buch-Verlag, Available at: https://www.sachverstaendigenrat-wirtschaft.de/fileadmin/dateiablage/gutachten/ jg201920/JG201920_Gesamtausgabe.pdf.

36. Schizas, Em., Gr. McKain, Br. Zhang et al. (2019). The Global RegTech 
Industry Benchmark Report, Cambridge Centre for Altrernative Finance, Available at: https:/www.jbs.cam.ac.uk/wp-content/uploads/2020/08/2019-12-ccaf-global-regtechbenchmarking-report.pdf.

37. Skinner, Chr. (2018). Innovation with compliance is difficult. TheFinanser, Jan 15, Available at: https://thefinanser.com/2018/01/innovation-compliance-difficult. $\mathrm{html} /$.

38. Skinner, Chr. (2019). The two big issues bank CEOs have with FinTech. TheFinanser, Sep 17 ${ }^{\text {th }}$, Available at: https://thefinanser.com/2019/09/the-two-bigissues-bank-ceos-have-with-fintech.html/.

39. Skinner, Chr. (2020a). The regulator's focus for 2020, TheFinanser, Jan 08, Available at: https://thefinanser.com/2020/01/the-regulators-focus-for-2020.html/.

40. Skinner, Chr. (2020b). Bye-bye FinTech. TheFinanser, Jan 15, Available at: https://thefinanser.com/2020/01/bye-bye-fintech.html/.

41. Srivastav, A. (2019). BigTech, FinTech and the Banks. AdvisoryCloud, June 07, Available at: https://www.advisorycloud.com/advisor-articles/bigtech-fintech-andthe-banks.

42. Valverde, C., Fr. Fernández (2019). The future of blockchain in the European banking system. Funcas SEFO, Vol. 8, No. 1, January 2019, Available at: https://www. sefofuncas.com/pdf/Carbo_8.1.pdf.

43. Wack, K. (2020). Banking 2025: The struggle to avoid becoming the 'dumb utility'. American Banker, Jan 9, Available at: https://www.americanbanker.com/news/ the-struggle-to-avoid-becoming-the-dumb-utility.

44. Wack, K. (2021). Big banks, Big Tech face off over swipe fees. American Banker, February 07, Available at: https://www.americanbanker.com/news/big-banksbig-tech-face-off-over-swipe-fees.

45. Williams, St. (2020). 20 Banking Realities for 2020. GonzoBanker, January 17, Available at: https://gonzobanker.com/2020/01/20-banking-realities-for-2020/.

46. Zaheer, S. (2015). How Banks Can Out-Innovate Startups and Tech Firms. The Financial Brand, August 12, Available at: http://thefinancialbrand.com/53490/ bank-technology-innovation-strategies/. 